\title{
APPLIED RESEARCH AS A METHODOLOGICAL INNOVATION IN JOURNALISM: theoretical, empirical and experimental dimensions
}

\author{
PESQUISA APLICADA COMO INOVAÇÃO METODOLÓGICA NO JORNALISMO: dimensões teórica, empírica e \\ experimental \\ INVESTIGACIÓN APLICADA COMO INNOVACIÓN METODOLÓGICA EN EL PERIODISMO: dimensiones teórica, \\ empírica y experimental
}

\section{Tássia Becker Alexandre}

Journalist. Doctor from the Postgraduate Program in Communication Sciences from Universidade do Vale do Rio dos Sinos (University of Vale do Rio dos Sinos) (Unisinos). Substitute professor of the Journalism Program at Universidade Federal de Mato Grosso (Federal University of Mato Grosso) (UFMT), campus Cuiabá. tassia.becker@gmail.com

0000-0003-2383-3358

\section{Maria Clara Aquino}

Researcher and professor of the Postgraduate Program in Communication Sciences Universidade do Vale do Rio dos Sinos (University of Vale do Rio dos Sinos) (Unisinos). Doctor and Master in Communication and Information from the Postgraduate Program in Communication and Information from Universidade Federal do Rio Grande do Sul (Federal University of Rio Grande do Sul) (UFRGS).jaquino@unisinos.br

0000-0001-8230-5921

Address: Universidade do Vale do Rio dos Sinos, PROGRAMA DE PÓS-GRADUAÇÃO EM COMUNICAÇÃO, Av. Unisinos, 950. Bairro Cristo Rei, 93.022-750, São Leopoldo, RS - Brasil.

Received: 02.16.2021.

Accepted: 04.16.2021.

Published: 07.01.2021.

\begin{abstract}
:
This paper discusses applied research as a perspective of methodological innovation in journalism by reporting the process of crafting a Doctor's Degree research about mobile journalism. For this, we relate innovation and crisis in journalism and address aspects related to applied research in the field. We also highlight the methodological processes developed in the thesis, reflecting on the articulation of what we call the theoretical, empirical and experimental dimensions of applied research. We approach the theoreticalmethodological experimentation in this type of investigation, the role of the academy for conducting applied research and the limitations and potential of this research perspective for journalism.
\end{abstract}

KEY WORDS: Applied research; Methodological processes; Mobile journalism; Innovation.

\section{Introduction}

Issues involving journalism and mobile devices have been the subject of reflection in the academic world, which observes the issue from different perspectives, such as from the transformations in journalistic practice, changes in formats, narratives and interfaces, new products and tools, and analyzes on the consumption of information and interaction between users and vehicles via mobile devices.

Based on a review of scientific journals, López-García et al. (2019), it is highlighted the extensive production related to mobile journalism in recent years. According to the authors, publications with a descriptive character, with a technological approach, are predominant, especially related to the influence of innovation on journalistic production. However, they emphasize that the field still has research gaps, with few analytical and practical studies referring to the emission, diffusion and reception of mobile content. 
With regard to practical studies, one of the perspectives that approach this line of inquiry is applied research, which aims to generate knowledge for application in solving specific problems, as well as using existing knowledge to solve not only the problem that motivated the investigation, but also expand knowledge and generate new questions on the subject (Prodanov \& Freitas, 2013). In journalism, Guerra (2016) understands that applied research has an intrinsic relationship with practice, seeking, from scientific research, to find solutions of a theoretical-practical nature for limitations or insufficiencies identified in a way of doing things.

In this context, this work aims to debate applied research as a perspective of methodological innovation in journalism through the report of the construction process of a doctoral research. In this context, this work aims to debate applied research as a perspective of methodological innovation in journalism ${ }^{1}$ through the report of the construction process of a Doctor's Degree research.

Initially, we made a brief approach to the crisis in journalism and the importance of thinking about the new in this scenario. Next, we approach applied research in the journalistic field, conceptualizing and understanding it as a way of methodologically innovating (Franciscato, 2017). Next, we detail issues related to the methodological development of the thesis on mobile journalism produced by one of the authors under the guidance of the other party. Finally, we present the considerations of this study.

We believe that reporting the experience of applied Doctor's Degree research allows to broaden the debate on this type of investigation, as well as to reflect on possibilities and challenges for this research in stricto sensu Postgraduate programs. Furthermore, we understand that the approach to the thesis construction process may be relevant for other researchers who intend to develop studies from this methodological perspective.

\section{Crisis and innovation in journalism}

Social and technological changes, especially in the last two decades, have had effects in different areas of the media and journalistic ecosystem. Carlón (2016) emphasizes that the media are going through a phase of intense changes related to the emergence of a new mediatization system and new social practices. The author clarifies that new forms of exploration, self-exploitation and domination are designed, distinct from those established by the massive media, in which subjects can make their speeches public through the so-called new media, causing the complexity of circulation.

\footnotetext{
${ }^{1}$ The term "indigenous" refers to original productions for smartphones and tablets that use exclusive content and differentiated treatment (Barbosa et al., 2013).
} 
In this context, it is observed that the popularization of the Internet and the cheapening of communication technologies ensured public participation in the production and dissemination of information on a faster and larger scale (Anderson, Bell \& Shirky, 2013). Still, journalistic practices were remodeled and digital platforms and devices, such as smartphones and tablets, emerged and contributed to changes in the way content is produced and consumed.

With regard to practice, Silva (2015) addresses the use of mobile devices in the production, investigation and transmission of news, highlighting that the new dynamics characterized by mobile technologies and the convergence process allows the journalist to be closer to the place where the events occur and carry out coverage more quickly and easily - which, as a result, affects the structure of the newsroom, production routines and information distribution strategies.

Regarding consumption, studies show that currently access to news on smartphones is greater compared to other digital media, especially through social media platforms and replacing or complementing other media (Newman et al., 2020). Consumption is increasingly individualized and users have also started to act on the content (Aguado, Feijóo \& Martínez, 2015). Also, the consumption habits of traditional vehicles have changed with the new generations (Thorson et al., 2015; Flamingo, 2019).

Another transformation related to the context corresponds to the decline in audiences, drop in revenue and decay of the main business model of traditional journalistic companies (advertising) (Newman et al., 2020; Pew Research Center, 2018). Journalism ended up being immersed in a context of impermanence in the industry, in the work environment and in careers (Deuze \& Witschge, 2016).

The challenging panorama ends up reflecting on what Henn and Oliveira (2015) call a systemic crisis, with effects on journalism's autonomy and identity. Anderson, Bell and Shirky $(2013$, p. 87) corroborate the authors by pointing out that perhaps the main change in post-industrial ${ }^{2}$ journalism lies in the weakening of what constitutes news and a journalistic organization, with "less clarity about what constitutes journalism itself".

The crisis theme is not, in fact, new to the journalistic field, which had its entire development marked by moments of instability and transition phases (Charron \& Bonville, 2016). The current crisis is the result of a set of changes that have been taking place in recent decades in journalism and social practices, making it necessary to avoid determinism and consider the historicity of the field. Likewise, it is necessary to

\footnotetext{
2 The term "post-industrial journalism" was created in 2001 by Doc Searls to suggest a journalism that is not organized according to the rules of the machinery of production (Anderson, Bell \& Shirky, 2013).
} 
emphasize the procedural character of the media, perceiving it as something in constant transformation.

As a result, it is not possible to predict exactly what the future of journalism will be. However, authors converge on the perspective that flexibility and innovation are central ideas for the survival of journalistic institutions. Anderson, Bell and Shirky (2013), as well as Singer (2014), recognize the challenges caused by recent changes in the field, but highlight the opportunities that open up to journalism. Researchers are emphatic that the only way to survive the crisis is to explore new possibilities, experimenting with forms of collaboration, using data analysis tools and creating other ways of narrating the events (Anderson, Bell \& Shirky, 2013).

In journalism, the understanding of what defines an innovation is centered on novelty, with innovation being understood as the process of creating or modifying journalistic practices, products and services. Among the authors who investigate the topic is Cabrera González (2016), for whom an innovation is the creation or modification of a product or service offered by the media through the integration of new technologies, routines and business models in its structure, organization, production processes and information dissemination, with the objective of diversifying the market with some competitive advantage or value creation.

A similar understanding is presented by Storsul and Krumsvik (2013), who classify five types of innovation in the media ecosystem: product or service innovation; process innovation; position innovation; paradigmatic innovation; and social innovation. From the authors, Dogruel (2017) develops a parallel between four types of innovation described by the authors (product, process, position and paradigm) and four dimensions in which change can occur (technological, in design or content, functional and organizational). According to the researcher, the novelty can fit into more than one classification and involve more than one type of change.

Another research that distinguishes approaches to innovation in journalism is that of Franciscato $(2010,2017)$, which lists three dimensions: technological innovation, which corresponds to procedures that involve the generation or application of technologies; organizational innovation, referring to changes in professional routines; and social innovation, related to the uses or social effects of interactive processes and interactions between society and journalistic organizations.

The understanding of innovation discussed so far has focused on professional practice - the products, processes and ways of organizing journalistic vehicles. However, this set includes one more level of what can be understood by innovation in journalism: 
innovation in research. The next section explores more about this aspect, relating it to applied research.

\section{Innovation in journalism investigations and applied research}

In addition to the market, academia has the potential to develop innovative projects, as it is a favorable environment for experimentation and transdisciplinarity. One of the ways to innovate in the academic environment is through methodological innovation, addressed by Franciscato (2017). According to the author, this type of innovation alludes to the conceptual field, configuring itself as an answer to a scientific problem, that is, a way of seeking to understand a given empirical reality when there is inadequacy of existing methodologies. According to Franciscato (2017, p. 37), "in a broad sense, innovation is a continuous process, and the task of science methodologists may be to define conditions, stages or degrees in which changes consolidate new methodological research models".

In order to debate the methodological innovation in the field, Franciscato (2017) developed a study with scientific articles related to digital journalism published between 2009 and 2013. The researcher found that two-thirds were empirical research and the rest was configured as theoretical or essay research. None of the work was applied research, which caught the author's attention because the methodology is "[...] useful for the development of journalistic processes and products in an environment constantly restructured by digital technologies" (Franciscato, 2017, p. 40).

Two other studies that analyze the annals of Brazilian academic congresses in communication and journalism corroborate the findings of Franciscato (2017). Machado and Rohden (2016), who investigated papers presented at the National Meeting of Journalism Researchers (SBPJor) between 2003 and 2007, verified the nonexistence of applied researches during the examined period. Lopez and Maritan (2015), in turn, identified four publications related to applied research in a sample of 353 event proceedings $^{3}$, published from 2000 to 2014 . However, they indicate that the production was concentrated in a few authors, "[...] which still demonstrates a reduced acceptance of this methodological perspective among peers" (Lopez \& Maritan, 2015, p. 13).

More specifically on communication and mobile journalism, in June 2020, we consulted the Capes Theses and Dissertations Catalog in order to know how Brazilian postgraduate courses in the area were approaching the theme and which works were

\footnotetext{
${ }^{3}$ Brazilian Congress of Communication Sciences (Intercom); National Meeting of the National Association of Postgraduate Programs in Communication (COMPÓS); National Meeting of Journalism Researchers (SBPJor); and National Meeting of Media History (Alcar).
} 
characterized as applied research. The search was developed from the terms "mobile communication", "mobile journalism", "mobile devices", "mobility", "ubiquity", "smartphone", "tablet" and "smartwatch", with the period of 2005-20194 and filter works related to Applied Social Sciences - areas of Communication, Visual Communication, and Journalism and Publishing.

The portal search identified 292 dissertations and theses that included one of the expressions in the title, abstract or keywords. From this total, we filtered out the works that were available for online access and that were directly related to mobile devices ${ }^{5}$, which resulted in 188 searches. In this sample, empirical investigations stood out, elaborated from different research methods and techniques, such as bibliographic and documental surveys, case studies, ethnographic immersions and exploratory research. Of the 188 studies, only seven (3.7\%) were entitled as applied research, five of which were related to journalism. In addition to these, another four indicated results aimed at solving practical problems. With these results, it was possible to better understand the national scenario of investigations on the subject and ratify the predominance of basic research in the area (Alexandre, 2021).

The panorama shown in the three studies and in the survey produced for the thesis is not, however, new to the field. It is, in fact, the result of the context that involves research in communication and journalism for over a century. At first, investigations in the area were marked by experimentation, however, over the years, the concern with the application of knowledge was relegated, being devalued compared to other theories and methods (Renó, 2014).

Given the current scenario, we understand that applied research is a way to explore and propose innovative ideas in the academic sphere. Returning to the concept addressed in the introduction to this study, applied research aims to produce knowledge for practical application in solving specific problems, enabling the use of different methods and investigation techniques (Prodanov \& Freitas, 2013).

In the journalistic field, following the understanding of Guerra (2016), applied research corresponds to the body of knowledge about journalism (own or derived from other areas), which systematizes concepts, foundations and relationships to account for a way of doing things. "From this systematization, a research problem is extracted, which is necessarily a practical problem - a limitation or insufficiency of the conventional way

\footnotetext{
${ }^{4}$ We chose to carry out the search for 15 years, also following the popularization of devices and the consolidation of mobile journalistic practices.

${ }^{5}$ Researches that addressed mobility, ubiquity and digital communication that did not have mobile devices among their main axes were disregarded.
} 
of doing things - for which an innovative solution is sought, capable of generating improved performance" (Guerra, 2016, p. 3, emphasis added). The researcher also clarifies that:

\begin{abstract}
Applied research "allows the operational formatting of ideas", which means to produce a conceptual systematization that can be operationalized, through technical methods and procedures, in the form of management mechanisms, processes and products that aim to offer solutions to the "objective or practical purpose" initially established (Guerra, 2016, p. 8).
\end{abstract}

Complementing this, Assis (2018, p. 140) understands that conducting applied research in the area "[...] is pertinent when real-life situations demonstrate the need for actions on them, either in order to change their directions, either complementing what already exists or creating something new, instead". For the author, it is through looking at the scenario in which journalism develops that it is possible to recognize when this applicability is necessary.

According to Guerra (2016), the solution produced from applied research is theoretical and practical in nature, which can advance to experimental development, creating new products and processes. This would be a way to complement the conceptual systematization developed from applied research - a demand, however, that arises from the research problem itself (Ibid.).

Santos (2015) corroborates Guerra, but considers that applied research should not be restricted to the experimental dimension. This is because, in experimental research, the investigator seeks the greatest possible control of variables in order to identify correlation and/or causality to refute or prove a certain hypothesis. In applied research, however, there is a tendency to observe the effects from a broader context, "[...] adopting an approach focused on the interconnection between the problem, the solution objectives, the profile of its users, their contexts of use and a certain degree of uncertainty, characterizing a complexity-oriented approach" (Santos, 2015, p. 20-21).

Thus, although focused on a practical problem, theory should not be dissociated from this type of investigation; on the contrary, it is what provides subsidies for the understanding and approach of the object of study (Guerra, 2016; Franciscato, 2006). Bibliographic research is configured as an initial and basic stage of applied research, allowing the theme to be substantiated, discovering similar studies and identifying techniques and procedures suitable for the research in question (Renó, 2014).

Added to theoretical research is the importance of empirical research on initiatives related to the object of study, as it allows knowing what has already been done and what still needs to be qualified. Data from empirical processes are used to design 
the solutions sought, "[...] where the researcher acts more actively using what he has collected in order to build something new or, at least, something that presents differences in relation to what, until then, was used to face the real problem that motivated the research activity" (Santos, 2015, p. 21).

Also, it is relevant to plan a possible testing of the elaborated proposal, including for conceptual proposals. As with innovative processes, testing is a relevant stage, allowing for the reflection of the idea's insertion into the social fabric, with opinions from possible users (Santos, 2015), and allowing for adjustments to be made to the contexts in which it will be inserted.

In addition to enabling the production of knowledge for practical application in the journalistic field, conducting applied research at the university has the potential to contribute to the education of future journalists, enabling them to work in an industry that is undergoing transformations in different spheres. Machado and Teixeira (2016, p. 107) corroborate this understanding, authors who stress that the crisis scenario accentuates the need to integrate teaching and applied research, where undergraduates can become "agents of change" from transdisciplinary projects with focus on developing new formats, languages, techniques, processes and prototypes for content production platforms.

This can also be a way to bring academia and the labor market closer together, as there is still a gap between the knowledge produced in the academic environment and the practices developed by media companies. A survey conducted by Weiss et al. (2020) in Latin America demonstrated, for example, that journalism students and educators were more likely to disagree that they were innovators than professionals who worked in their own or third-party companies, which, according to the authors, may be related to the fact that students and faculty are less active in the news industry. Weiss et al. (2020) also consider that perhaps Latin American universities are not promoting innovation as much as students and faculty would like, and that academia may be lagging behind in promoting an innovative environment.

After approaching applied research in journalism, understanding it as a perspective of innovation in the field, we present below an account of the methodological development process of a Doctor's Degree research related to mobile journalism.

\section{Methodological processes of applied Doctor's Degree research}

The crisis scenario in journalism highlighted at the beginning of this work, in which traditional media vehicles find it difficult to adapt to the digital age and the current 
changes in the field, fostered the development of a Doctor's Degree research that could shed light on some related issues the theme, especially with regard to mobile journalism (Alexandre, 2021).

Assuming that the specific features of mobile devices can make narratives more complete, interesting and accessible to users, the thesis sought to answer the following issue: Considering the context of mobility, the specificities of mobile devices and access to news on these supports, how to qualify the production of journalism for smartphones and tablets through an indigenous mobile journalistic language?

With the proposal to develop parameters that could help journalistic production, the thesis was characterized as an applied research, combining different methodological procedures and investigation techniques. As the contact with theories, methods and empirical object deepened, we realized the need to develop other processes to get closer to the objective of the study.

Theory and method were designed in an integrated way in the thesis, enabling the construction and experimentation of specific approaches to research. This need for theoretical-methodological experimentation was even more accentuated due to the specificity of applied research, a type of investigation never carried out by us and which is also not common in stricto sensu Postgraduate Programs in the area, as highlighted above.

Due to the bias towards practice, we also realize the importance of an epistemological surveillance, an action that takes place, according to Bourdieu, Chamboredon and Passeron (2010), through questioning the techniques and concepts used, from the abandonment to the automatic application of models and procedures already used and through the continuous exercise of rethinking each and every operation performed. This understanding is in line with what Assis (2018) argues, that applied research should develop from a dialectical movement between envisioning possible practical solutions while making criticism, because,

Otherwise, applied research will be nothing more than an alleged academic validation of interests previously outlined by the market, incurring the greatest error of reinforcing harmful journalistic practices or, at the very least, of making believe that the applicability of academic research results in something that it is not (Assis, 2018, p. 146).

Thus, as Franciscato (2006) underlines, it is essential for an applied research to build a basic theoretical framework, providing the concepts that underlie the characterization and definition of phenomena. With this theoretical support, it is possible 
to outline ways to operationalize the researcher's intervention in reality, supporting the production of knowledge.

With this in mind, the research was structured from three dimensions: theoretical, empirical and experimental. The theoretical dimension corresponded to the bibliographical research based on scientific productions related to the themes explored in the study, such as mobile journalism, innovation and information architecture. The empirical dimension included steps that allowed understanding what was already produced by journalistic companies for the mobile environment, as well as producing data related to the way people use their smartphones and consume news on mobile devices. The articulation of these two dimensions was the foundation for the conceptual elaboration of parameters for a native language for mobile devices, which further advanced to an experimental dimension, in which a prototype of a journalistic product for smartphones was developed based on some proposed guidelines.

Figure 1 illustrates the articulation between the dimensions of applied research that make up the thesis. The double direction arrows are intended to demonstrate that the process was not linear, in which each dimension was built and revisited according to the development of the investigation. The experimental dimension needed theoretical and empirical dimensions to be materialized; in the same way, theories and empirical were thought with a view to the elaboration of the prototype, and make sense from the experimental process.

Figure 1 Dimensions of applied research developed in the thesis.

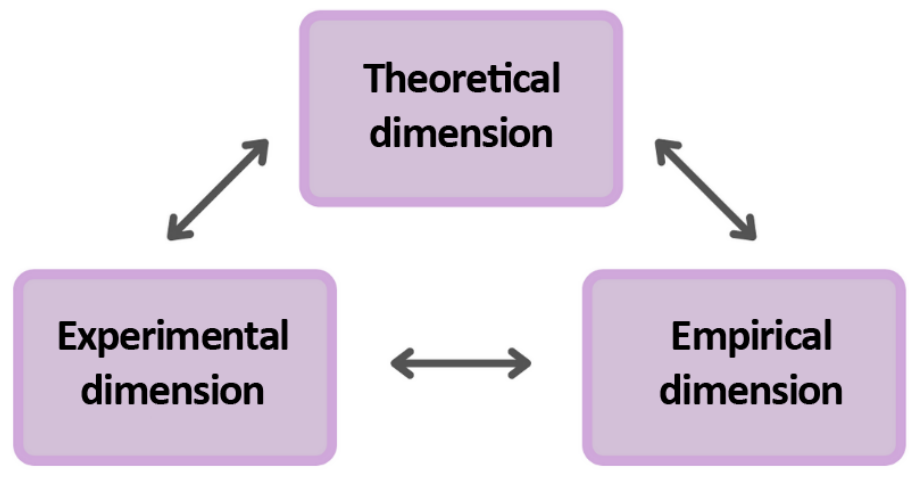

Source: Produced by the authors (2021)

The methodological procedures of the thesis were delineated from an adaptation of the projectual design methodology, which aims to organize and delimit the steps, processes and techniques necessary for the elaboration of a product. Among the various conceptions of this methodology, we are based on Project $E$, which is intended for the 
development of user-friendly graphical interfaces for digital-virtual interactive systems and products, and consists of six phases: strategy, scope, structure, skeleton, aesthetics and execution (Meurer \& Szabluk, 2010).

The strategy stage integrates the definitions of design issues, identification of scenarios, what is the situation in which one intends to arrive, equalization of design factors and taxonomy. The scope phase deals with organizing the content into categories and starting the definition of features and tools. The structure step is dedicated to the product organization chart. The next phase, skeleton, proposes the structural organization of the content. In the aesthetic stage, the graphic-visual identity of the project is defined. And, finally, the execution phase corresponds to product programming, in this case, the production of the prototype (Meurer \& Szabluk, 2010).

Figure 2 represents the timeline for the construction of the thesis, with an indication of the empirical and experimental processes carried out. We consider that theoretical research was the guiding principle at all stages, so we did not indicate a single moment for its realization.

Figure 2 Processes developed in the thesis.

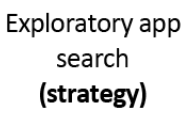

(1)

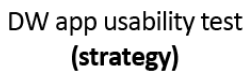
(strategy)

(3)

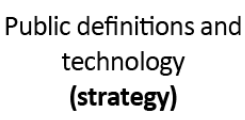

(5)
Prototype production

(execution)

(7)

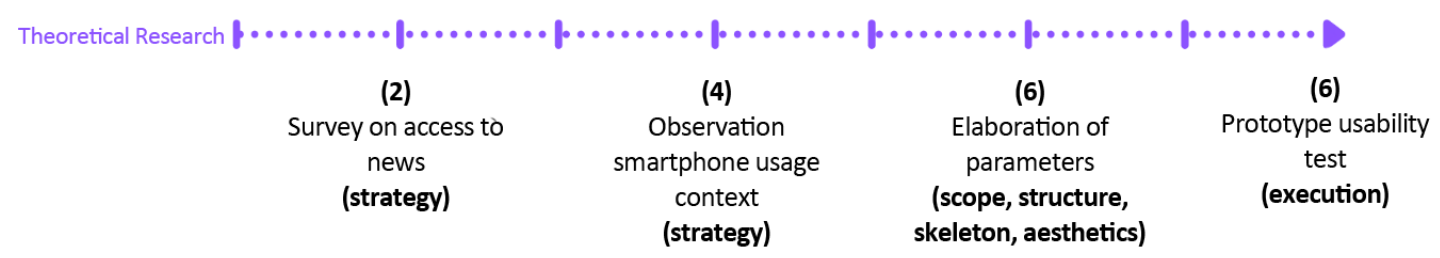

Source: Produced by the authors (2021)

Next, we approach the synthesis of each methodological process developed in the research. As the focus of this study is the methodological construction of the investigation, the results of the steps will not be explored. Details on the methodology and data produced from these procedures can be found in the thesis (Alexandre, 2021).

\section{a) Exploratory research in journalistic apps}

In order to elaborate the scenario identification process, related to the strategy stage, an exploratory exercise of observation of journalistic applications (apps) for mobile 
devices was carried out. Due to the large number of applications found, we chose to develop this activity in two phases. The first corresponded to the general description of 219 Brazilian and international journalistic apps, observing aspects related to seven characteristics of web journalism: multimediality, ubiquity, hypertextuality, instantaneity, memory, interactivity and personalization (Canavilhas, 2014). The second phase was characterized by the in-depth description of two applications, DW and Quartz, from six categories (interface, interactivity and immersion, content, personalization, distribution and context).

These explorations took place in different periods of the research development, between 2017 and 2020, and allowed for an understanding of what was already being done in the area, the functioning of these productions, as well as raising characteristics that could be added to the proposed parameters.

\section{b) Survey on access to news}

In order to understand issues about the consumption of news on mobile devices, contributing to the delimitation of the public, in 2017 we carried out a survey through an online questionnaire with 432 Brazilian Undergraduate and Postgraduate Students. According to Prodanov and Freitas (2013), a survey is a type of research useful for studying the behavior of a particular audience. Despite the quantitative bias, this process was used to explore and learn more about the issue, generating data that could support other stages of the thesis.

\section{c) Usability test in DW application}

Another process related to the strategy stage corresponded to a usability test in the DW application, from the Deutsche Welle company. Usability testing is a methodological tool that allows evaluating the way users access and interact with an interface, verifying which attributes make browsing more efficient and beneficial to the public (Nielsen \& Loranger, 2007). The experience was carried out in 2018 with nine Postgraduate students in Communication from Rio Grande do Sul, from an adaptation of the STBI method (Interviews Based on Scenarios and Tasks) (Agner, Gomes \& Muniz, 2014), and allowed the identification of aspects related to the effectiveness and satisfaction of browsing the app, such as the most used resources and difficulties/facilities in interacting with the product. 


\section{d) Observation of the context of smartphone use}

In order to complement the data obtained in the online survey with Brazilian students, in 2019 we carried out an observation of the context of use and access to news on smartphones by eight Postgraduate students in Communication residing in Spain. For this stage, data were collected on the use of battery/mobile data from the participants' devices over five weeks and individual semi-structured interviews were carried out. The device data contained the time and/or percentage of battery usage of the installed applications, indicating the most used ones. Individual interviews, in turn, dealt with usage habits and consumption of journalistic content on mobile phones. This stage helped to broaden the understanding of how young people use their devices and seek, access and interact with news.

\section{e) Definition of audience and technology}

From the theoretical research and the empirical processes carried out, we defined that the proposed parameters and the prototype would be designed for young higher education students and smartphones. The choice for this group was based on research that reveals a close relationship between them and mobile devices. Young people browse the Internet and use devices the most, and they are the ones who consume the most news on such devices (IBGE, 2020). Another reason that contributes to this option is the importance of investigating the younger generations with greater attention, especially given the scenario of falling audiences and aging of the public in traditional media. On the other hand, the focus on university students is related to the fact that a large portion of higher education students in Brazil are in the younger age groups of the population (INEP, 2019). Also, because we are inserted in the university environment, which made it easier to get closer to this audience and to carry out the research.

The choice to build the prototype for smartphones was necessary due to the time and resources available to produce the object. We understand that there are differences between the characteristics of mobile devices, as well as the way news is accessed on each type of device. The smartphone was selected because it is more used than the tablet in the country (FGV, 2020). Also, for concentrating the largest access to mobile Internet in Brazil (CETIC.BR, 2020) and due to the record of increased consumption of news on these devices in recent years (Newman et al., 2020).

\section{f) Preparation of mobile journalistic language parameters}

The processes developed up to this stage of the research enabled the production of knowledge about the object of study, gathering references for the proposition of 
parameters for the autochthonous journalistic language for mobile devices. The conceptual proposal was organized into five macro-categories (public, content, narrative, interface and structure), and 31 elements (or sub-categories), selected from the theoretical and empirical research carried out. The constructed arrangement served as a guide for the prototype production, but we believe that it can be adapted for other investigations and productions with different purposes and audiences, considering that it contemplates the main aspects that must be planned in a journalistic product for mobile devices. In the thesis it is possible to verify the details of the proposal.

\section{g) Production of mobile journalistic product prototype}

The prototype development aimed to materialize and test some proposed parameters. Depending on the time and resources available, the object corresponded to a sample of the screens of a journalistic production for smartphones aimed at the young audience, presenting high fidelity in appearance, but with some restrictions on its functionality and interactions.

The prototype was built in 2020 using the Figma platform ${ }^{6}$, which allows the development of the interface and prototype of simple interactions between elements, and had the help of a professional from the User Experience area to refine the design. The object was supplied with contents and components of the visual identity of Beta Redação ${ }^{7}$, an experimental project of the Journalism course at the Universidade do Vale do Rio dos Sinos (Vale do Rio dos Sinos University) (Unisinos). The partnership was created to streamline the production process, in addition to establishing a bridge with the teaching of the profession and valuing the experimental practices of graduation. The materials were adapted to meet the specifics of the proposal. In all, 20 different pages were designed, including home screen, menu, editorials and news, as shown in Figure 3.

\footnotetext{
${ }^{6}$ Available at: https://www.figma.com/.

${ }^{7}$ Available at: https://medium.com/betaredacao.
} 
Figure 3 Overview of prototype screens.

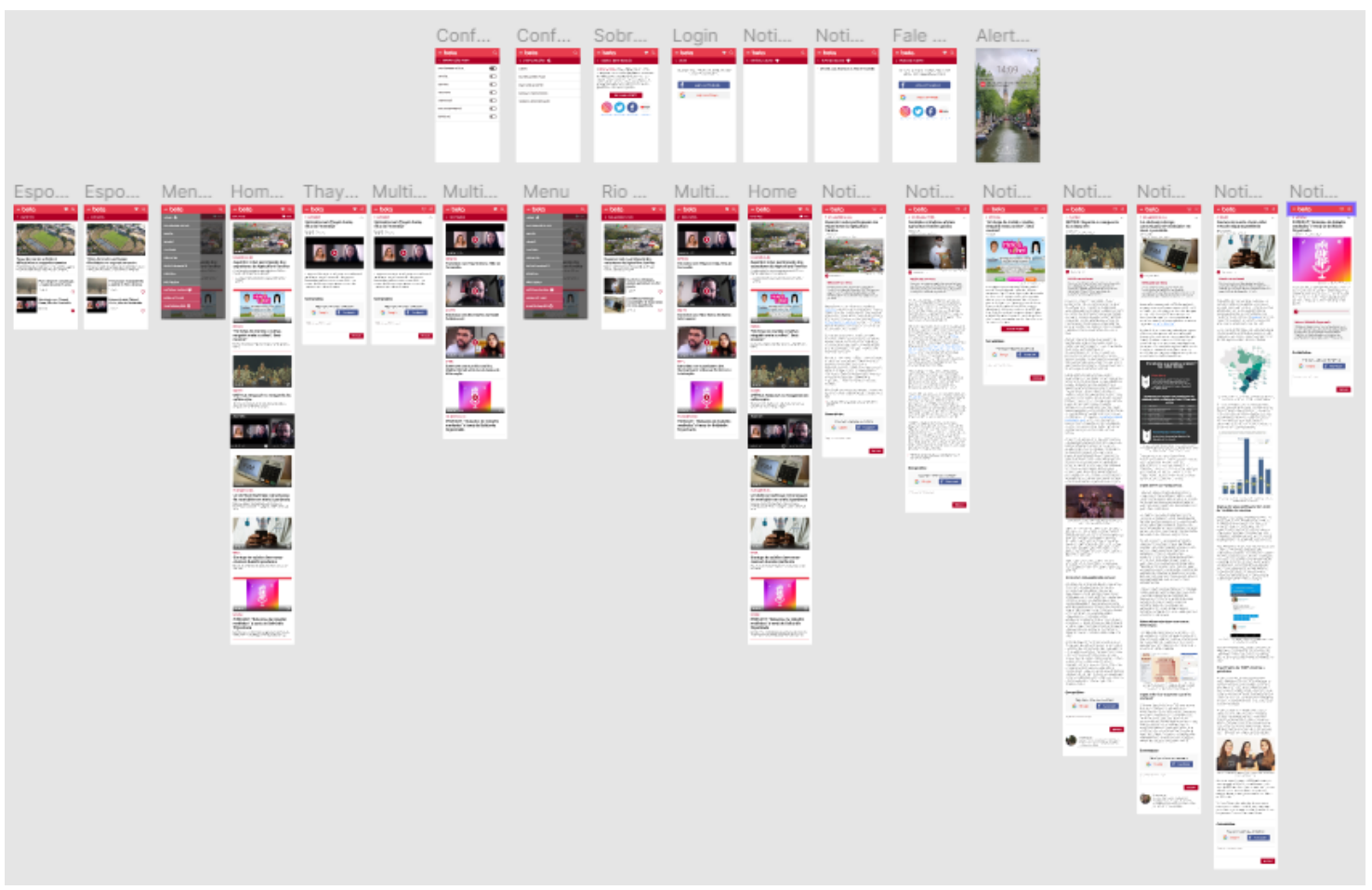

Source: Produced by the authors (2020)

\section{h) Usability test on prototype}

After developing the prototype, in 2020 a usability test was carried out on the object with 16 higher education students residing in Rio Grande do Sul, also following an adaptation of the STBI method (Agner, Gomes \& Muniz, 2014). Due to the Covid-19 pandemic, the assessment was performed remotely, through individual video calls, in which each student shared their smartphone screen and made comments while performing the tasks proposed by the researchers. The purpose of the evaluation was to assess ease of access and navigation satisfaction, focusing on finding information and using the object's resources. The experience made it possible to better understand the practical application of mobile journalistic language parameters and to identify the participants' perception of some proposed guidelines.

\section{Reflections on the applied research process}

The development of the thesis allows us to make some reflections related to the accomplishment of applied researches in the academy. Initially, we highlight how the theoretical-methodological construction as a whole was fundamental for the elaboration of the parameters and production of the prototype. The intention to reach a result that could be tested existed since the research project, but at the beginning of the doctorate, we still didn't know if we would advance to this phase. It was, then, from the 
experimentation of theories, methods and techniques during the investigation trajectory that it became possible to gather the subsidies to carry out the proposition.

In reference to the experimental stage, we evaluated that the construction of the prototype was beneficial to the research, making it possible to complement theoretical and empirical findings, test some of the parameters with users and better understand how the journalistic production process for smartphones takes place. In addition, prototyping and testing revealed that it is essential to understand the uses that the public will make of the product.

Regarding innovative processes and applied research, the development of the thesis reveals some relevant aspects for understanding how this type of project can be thought of in the academic environment. A first point concerns the advantages that the university provides for conducting innovative processes, including the issue of time. We had almost four years to investigate and propose the parameters of journalistic language for mobile devices, a period that companies rarely make available to their teams. The academy allows for a greater level of depth and maturity of the project before the idea is inserted into the social fabric. It is clear that the results of an innovation are unpredictable, both those projected by educational institutions and business organizations, as they depend on the uses and appropriations made by society. However, perhaps the lack of research and planning time are among the reasons that explain the discontinuity of experiences launched by the media industry, such as some journalistic mobile apps and magazines for tablets. In an ideal scenario, universities and media would work together to think of solutions to the problems faced by the field, as some media labs already do.

Another benefit of universities is to bring together, in the same space, researchers and professionals from different areas, since multidisciplinary interaction is necessary for these projects, as demonstrated by the elaboration of the research. Without references from other fields of knowledge, conversations with colleagues from different courses and the help of a User Experience professional, it would have been more difficult, timeconsuming and costly to propose the parameters and build the prototype.

The investigation also indicated the potential that applied research has to integrate undergraduate and graduate studies. In the thesis, the partnership occurred through the inclusion of content produced by Beta Redação in the prototype, which was essential to streamline its preparation, but in other studies, participation can take place in other ways, such as seeking solutions to problems related to training professional and involve students in all stages of design and construction of the project, for example. We understand that collaboration favors both sides, combining theory and practice, 
reducing the distance between undergraduate and master's and doctoral courses and enabling the qualification of journalism teaching, as Machado and Teixeira (2016) have already underlined.

Despite the opportunities, we realized that developing applied research is not so simple - which may also explain why this perspective of investigation is not so recurrent in communication and journalism, even though we are an Applied Social Science. In some situations, we note the lack of knowledge and/or withdrawal of this type of study in academic master's and doctoral programs, making it difficult to form a debate on the role of applied research in scientific production in the field. Due to our own lack of experience, we had difficulties in understanding which theories and methods could help in the investigation of the problem - which ended up also driving the theoreticalmethodological experimentation highlighted above.

Staff and budget constraints are one more factor that can prevent applied research from moving to an experimental stage. In the case of the thesis, the construction of the prototype had no financial cost, however, by evaluating the options that exist for the production of websites and mobile applications, we would be able to test more elements if we had the amounts to fund programs and/or the participation of more researchers and professionals in the project.

Despite the challenging scenario, the Doctor's Degree research showed that applied research is a possible way to critically reflect on journalism and plan solutions that can contribute to journalistic practices, especially in this context of crisis that we are going through. That said, in the next section we address the final considerations of the study, with more general notes on the subject.

\section{Considerations}

This study sought to debate applied research as a perspective of methodological innovation in journalism through the report of the construction process of a Doctor's Degree research. Despite being related to a specific thesis, we believe that the work can contribute to other studies in journalism and communication that aim to work from applied research.

In the context of crisis in journalism, we believe that scientific research has an important role to play in helping to reflect on the scenario and debate possible paths in the face of the intense changes that affect the field. Given the complexity of the phenomena, we understand that resorting to methodologies and techniques usually employed in investigations may not provide sufficient support for understanding the problems investigated, thus giving rise to the possibility of methodological innovation. 
As Franciscato (2017, p. 43) points out, "[...] an eventual implementation of innovative methodological procedures could offer greater conditions for the formulation of new ways of thinking about journalism, as well as the proposition of new concepts and methodological approaches to object".

In this direction, we believe that applied research can be a productive way to seek solutions and develop innovative projects in journalism. The reported thesis development process highlights challenges in carrying out this type of investigation, both due to resource limitations and the very nature of this research perspective. However, we emphasize the possibilities of theoretical-methodological experimentation that open up from applied research, in testing other approaches - thus enabling the promotion of methodological innovation (Franciscato, 2017).

With the report, we also seek to demonstrate the articulation and interaction between what we call "dimensions of applied research", the theoretical, empirical and experimental processes. As it turns to practice, applied research may have its scientificity questioned - a fear that only solutions to the problems identified in journalistic practice are sought without critical reflection on it. However, we emphasize how much theoretical grounding and problematization are essential in this type of investigation, because, as Franciscato (2006), Guerra (2016) and Renó (2014) point out, it is from theory that we can tension the object and base the propositions. Likewise, it is precisely the reflective process on this action that will differentiate applied research from the simple validation of what is done in the market (Assis, 2018).

The consulted references and the thesis construction process also allow us to understand that the experimental stage is configured as a way for the production and application of knowledge, as proposed by Guerra (2016). However, from this research perspective, conceptual propositions may also arise for consultation and/or application by other students, researchers and professionals.

The survey on applied research in dissertations and theses on mobile communication, mentioned in this work, also shows its potential to address different issues related to the same area of journalism. However, this mapping, together with studies such as those carried out by Franciscato (2017), Machado and Rohden (2016) and Lopez and Maritan (2015), shows that applied research is still not a recurrent perspective in journalism investigations. We believe that the lack of knowledge and/or departure from this type of research in academic master's and doctoral programs and the absence of a methodological plan aimed at projecting results are among the factors that contribute to this scenario. 
Another point that can make this type of application of science unfeasible is the lack of resources to develop solutions based on knowledge generated through theoretical and empirical research. In many cases, there is a need for trained professionals and the involvement of other areas of knowledge to work on projects, which can inhibit the proposition of research in an applied format. The doctoral thesis reported in this work exemplifies these limitations.

We highlight the potential of the university to be the space for the development of applied research, adopting a proactive posture in relation to the market and proposing solutions to problems that affect society. In theory, the academy is not tied to the rhythm and marketing logics, which allows dedicating time to theoretical and methodological deepening. It also brings together specialists from different areas, who can work collectively based on the approaches and interests of each science.

Finally, we believe that knowledge related to applied research needs to be shared so that more researchers can become interested in this investigative modality. An initiative in this regard consists of the Adelmo Genro Filho Award, from the Brazilian Association of Journalism Researchers (SBPJor), which since 2018 has had a category focused on products and projects characterized as having practical application. Another possibility refers to the debate on the subject in congresses and in undergraduate and graduate courses, familiarizing researchers with applied research and possibly increasing its acceptance.

\section{References}

Agner, L., Gomes, L. A. De M. \& Muniz, M. I. (2014). Jornalismo para tablets: interações gestuais em um aplicativo de notícias. Ação ergonômica, 9(1). Available at: https://www.revistaacaoergonomica.org/revista/index.php/ojs/article/view/201/2 00.

Aguado, J. M., Feijóo, C. \& Martínez, I. J. (2015). A mobile revolution inside a digital Revolution. (J. M. Aguado, C. Feijóo, I. J. Martínez, Orgs.). Emerging Perspectives on the Mobile Content Evolution. Hershey, PA: IGI Global. DOI: 10.4018/978-14666-8838-4.

Alexandre, T. B. (2021). Linguagem jornalística autóctone para dispositivos móveis. (Tese de doutorado). Programa de Pós-graduação em Ciências da Comunicação, Universidade do Vale do Rio dos Sinos, São Leopoldo, RS, Brasil.

Anderson, C. W., Bell, E. \& Shirky, C. (2013) Jornalismo pós-industrial: adaptação aos novos tempos. Revista de Jornalismo ESPM, 2(5), 30-89.

Assis, F. De. (2018). Pesquisa aplicada em jornalismo: o desafio da construção do objeto. Comunicação \& Inovação, 19(41), 133-148. Available at: https://seer.uscs.edu.br/index.php/revista_comunicacao_inovacao/article/view/55 18. 
Barbosa, S., Silva, F. F. Da, Nogueira, L. \& Almeirda, Y. (2013). A atuação jornalística em plataformas móveis: Estudo sobre produtos autóctones e a mudança no estatuto do jornalista. Brazilian Journalism Research, 9(2), 10-29. Available at: https://bjr.sbpjor.org.br/bjr/article/view/549.

Bourdieu, P., Chamboredon, J. \& Passeron, J. (2010). Ofício de sociólogo: metodologia da pesquisa na sociologia. 7. ed. Petrópolis: Vozes.

Cabrera González, M. A. (2016). La innovación: concepto y taxomización. In: Sábada Chalezquer, C., García-Avilés, J. A. \& Martínez Costa, M. D. P. (Orgs.). Innovación y desarrollo de los cibermedios en España. Madri: EUNSA.

Canavilhas, J. (Org.) (2014). Webjornalismo. 7 características que marcam a diferença. Covilhã: LabCom Books.

Carlón, M. (2016). Después del fin: una perspectiva no antropocéntrica sobre la post-tv, el post-cine y youtube. Buenos Aires: La Crujía.

Cetic.Br. (2020). TIC Domicílios e Usuários 2019. Available at: https://www.cetic.br/media/analises/tic_domicilios_2019_coletiva_imprensa.pdf.

Charron, J. \& Bonville, J. de. (2016). Natureza e transformação do jornalismo. Florianópolis: Insular; Brasília: FAC Livros.

Deuze, M. \& Witschge, T. (2016). O que o Jornalismo está se tornando. Parágrafo, 4(2). Available at: http://revistaseletronicas.fiamfaam.br/index.php/recicofi/article/view/478/445.

Dogruel, L. (2017). O que há de tão especial nas inovações midiáticas?: uma caracterização do campo. Contemporanea, 15(01), 25-46. Available at: https://periodicos.ufba.br/index.php/contemporaneaposcom/article/view/22167.

FGV. (2020). 31 a Pesquisa Anual do Uso de TI. Available at: https://eaesp.fgv.br/producao-intelectual/pesquisa-anual-uso-ti.

Flamingo. Reuters Institute. (2019). How Young People Consume News. and The Implications For Mainstream Media. Available at: https://reutersinstitute.politics.ox.ac.uk/our-research/how-young-peopleconsume-news-and-implications-mainstream-media.

Franciscato, C. E. (2017). A inovação metodológica como problema na pesquisa em jornalismo digital. Contemporanea, 15(01), 25-46. Available at: https://periodicos.ufba.br/index.php/contemporaneaposcom/article/view/21513.

Franciscato, C. E. (2010). Uma proposta de incorporação dos estudos sobre inovação nas pesquisas em jornalismo. Estudos em Jornalismo e Mídia, 7(01). Available at: https://periodicos.ufsc.br/index.php/jornalismo/article/view/19846924.2010v7n1p8.

Franciscato, C. E. (2006). Considerações metodológicas sobre a pesquisa aplicada em jornalismo. In Anais do $4^{\circ}$ Encontro Nacional da Associação Brasileira de Pesquisadores em Jornalismo, 2006, Porto Alegre, RS, Brasil.

Guerra, J. L. (2016). Qualijor - Sistema de Gestão da Produção Jornalística orientado para a qualidade editorial: Pesquisa Aplicada e de Desenvolvimento Experimental em Jornalismo. E-compós, 19(3). Available at: https://www.e-compos.org.br/ecompos/article/view/1291.

Henn, R. \& Oliveira, F. M. De. (2015). Jornalismo e movimentos em rede: a emergência de uma crise sistêmica. Revista Famecos, 22(3). Available at: https://revistaseletronicas.pucrs.br/ojs/index.php/revistafamecos/article/view/205 60. 
IBGE. (2020). Pesquisa Nacional por Amostra de Domicílios Contínua 2018. Available at: https://biblioteca.ibge.gov.br/visualizacao/livros/liv101705_informativo.pdf.

INEP. (2019). Censo da Educação Superior 2018. Available at:

http://portal.inep.gov.br/web/guest/sinopses-estatisticas-da-educacao-superior.

López-García, X. et al. (2019). Periodismo móvil: Revisión sistemática de la producción científica. Comunicar, 59(27), 9-18. Available at:

https://www.revistacomunicar.com/index.php?contenido $=$ detalles \&numero $=59 \&$ articulo=59-2019-01.

Lopez, D. C. \& Maritan, M. (2015). A evolução do método: memória das pesquisas experimental e aplicada nos estudos brasileiros de jornalismo. In Anais do $10^{\circ}$ Encontro Nacional de História da Mídia, Porto Alegre, RS, Brasil.

Machado, E. \& Rohden, J. (2016). Metodologias de pesquisa aplicadas ao jornalismo: Um estudo dos trabalhos apresentados na SBPJor (2003-2007). Brazilian Journalism Research, 12(1), 228-245. Available at: https://bjr.sbpjor.org.br/bjr/article/view/828.

Machado, E. \& Teixeira, T. (2016). Innovation as an essential part of journalism education in contemporary societies. Journal of Applied Journalism \& Media Studies, 5(1), 103-116. Available at: https://www.ingentaconnect.com/content/intellect/ajms/2016/00000005/000000 01/art00008? crawler $=$ true.

Meurer, H. \& Szabluk, D. (2010). Projeto E: aspectos metodológicos para o desenvolvimento de projetos dígito-virtuais. Ação ergonômica, 5(2).

Newman, N. et al. Reuters Institute. (2020). Digital News Report 2020. Oxford: Reuters Institute; University of Oxford. Available at: http://www.digitalnewsreport.org/.

Nielsen, J. \& Loranger, H. (2007). Usabilidade na web. Projetando websites com qualidade. Rio de Janeiro: Elsevier.

Pew Research Center. (2018). 5 facts about the state of the news media in 2017. Available at: http://www.pewresearch.org/fact-tank/2018/08/21/5-facts-aboutthe-state-of-the-news-media-in-2017/.

Prodanov, C. C. \& Freitas, E. C. de. (2013). Metodologia do trabalho científico. Métodos e técnicas da pesquisa e do trabalho acadêmico. 2. ed. Novo Hamburgo: Editora Feevale.

Renó, D. (2014). Pesquisa aplicada em comunicação: uma tendência necessária. Comunicação \& Sociedade, 36(1), 7-30. Available at: https://repositorio.unesp.br/handle/11449/135421.

Santos, M. C. dos. (2015). Jornalismo, mobilidade e realidade aumentada: notas sobre possibilidades de utilização. In: Canavilhas, J. \& Satuf, I. (Orgs.). Jornalismo para Dispositivos móveis: produção, distribuição e consumo. Covilhã: Livros Labcom.

Silva, F. F. da. (2015). Jornalismo Móvel. Salvador: EDUFBA.

Singer, J. B. (2014). Sem medo do futuro: ética do jornalismo, inovação e um apelo à flexibilidade. Comunicação e Sociedade, 25, 49-66.

Storsul, T. \& Krumsvik, A. H. (2013). What is Media Innovation? In: Storsul, T. \& Krumsvik, A. H. (Eds.). Media Innovations. A Multidisciplinary Study of Change. Gotemburgo: Nordicom.

Thorson, E. et al. (2015). News use of mobile media: A contingency model. Mobile Media \& Communication, 3(2), 1-19. Available at: https://journals.sagepub.com/doi/10.1177/2050157914557692. 


\section{Qrevisto \\ Observatório}

e-ISSN No. 2447-4266

Palmas, v. 7, n. 3, p. 1-22, jul.-set., 2021

Weiss, A. S. et al. (2020). Defining Journalism Innovation in Latin America: Exploration into perceptions among educators, students, and journalists. Journalism \& Mass Communication Educator, 75(4), 419-435. Available at: https://journals.sagepub.com/doi/abs/10.1177/1077695820935327?journalCode= jmcb.

\section{RESUMO:}

Este trabalho objetiva debater a pesquisa aplicada como uma perspectiva de inovação metodológica no jornalismo por meio do relato do processo de construção de uma investigação de doutorado sobre jornalismo móvel. Para tanto, relacionamos inovação e crise no jornalismo e abordamos aspectos referentes à pesquisa aplicada no campo. Também destacamos os processos metodológicos desenvolvidos na tese, refletindo sobre a articulação do que denominamos como dimensões teórica,

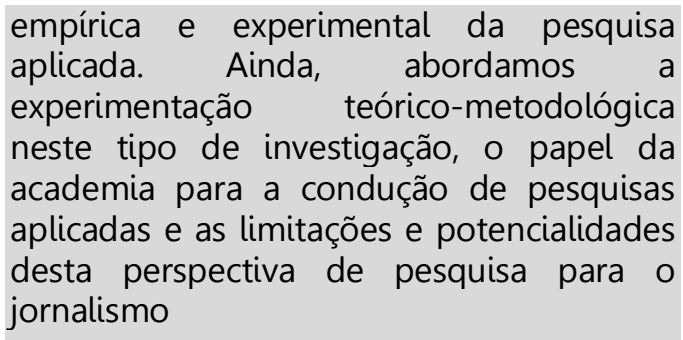

PALAVRAS-CHAVES: Pesquisa aplicada; Processos metodológicos; Jornalismo móvel; Inovação.

perspectiva de investigación para el
periodismo.

PALABRAS CLAVE: Investigación aplicada; Procesos metodológicos; Periodismo móvil; Innovación.

\section{RESUMEN:}

Este artículo tiene como objetivo discutir la investigación aplicada como una perspectiva de innovación metodológica en el periodismo a través del proceso de construcción de una investigación doctoral sobre periodismo móvil. Relacionamos innovación y crisis en el periodismo y abordamos aspectos relacionados con la investigación aplicada en el campo. Destacamos también los procesos metodológicos desarrollados en la tesis, reflexionando sobre la articulación de lo que llamamos las dimensiones teórica, empírica y experimental de la investigación aplicada. Abordamos la experimentación teóricometodológica en este tipo de investigación, el papel de la academia para la realización de la investigación aplicada y las limitaciones y potencialidades de esta 